\title{
First record of Coleia Broderip (Crustacea, Decapoda, Coleiidae) from the Upper Triassic of Japan
}

\author{
Híroaki Karasawa ${ }^{1}$, Fumio Takahashi ${ }^{2}$, Eiji Doi ${ }^{3}$ \& Hideo Ishida ${ }^{3}$ \\ ${ }^{1}$ Mizunami Fossil Museum, Yamanouchi, Akeyo, Mizunami, Gifu 509-6132, Japan; ${ }^{2}$ Mine City Museum of \\ History and Folklore, Omine, Mine, Yamaguchi 759-2292, Japan; ${ }^{3} \mathrm{c} / \mathrm{M}$ Mine City Museum of History and \\ Folklore, Omine, Mine, Yamaguchi 759-2292, Japan
}

Keywords: Crustacea, Decapoda, Coleiidae, Coleia, Triassic, Japan

\begin{abstract}
We record the discovery of Coleia Broderip (Eryonoidea: Coleiidae) from the Nakatsuka Formation, Mine Group, Upper Triassic of Japan. The specimens were collected from shales exposed at Tsubuta, Sanyo-cho (Yamaguchí Prefecture), Coleia co-occurs there with fragments of a penaeoid, bivalves, Halobia spp., ammonites, and plants.
\end{abstract}

\section{Introduction}

In his review of Mesozoic decapods from Japan, Karasawa (2001) listed 22 species in 17 genera from Lower Jurassic (Toarcian) to Upper Cretaceous (Maastrichtian) deposits. Amongst these, Uncina sp. ('Uncinidea Beurlen', Uncinidae Beurlen), described from the Toarcian Toyora Group in Yamaguchi Prefecture by Karasawa (2002), is the oldest record in Japan. The purpose of the present note is to record the discovery of Coleia Broderip (Eryonoidea de Haan, Coleiidae van Straelen) in the Nakatsuka Formation (Mine Group, Upper Triassic), deposited on the Akiyoshi Terrane (SW Japan). The specimens were collected from shales exposed at Tsubuta, Sanyo-cho (Yamaguchi Prefecture). Coleia co-occurs there with fragments of a penaeoid, bivalves, Halobia spp., ammonites, and plants. Tokuyama (1962) indicated, based upon bivalves, that the age of the Nakatsuka Formation was Carnian, i.e., Late Triassic. The presence of the ammonite Trachyceras cf. desatoyense Johnston in this formation also shows that it to be of Early Carnian date (Ishibashi et al., 1990).

\section{Results}

The Coleiidae comprises five genera, Coleia, $\mathrm{Hel}$ lerocaris van Straelen, Proeyon Beurlen, Pseudocoleia Garassino \& Teruzzi, and Tropifer Gould (Glaessner, 1969; Duffin, 1978; Garassino \& Teruzzi, 1993; Schweigert, 2000). Hitherto, the known members of Coleia have been recorded from the Lower and Upper Jurassic, and possibly Lower Cretaceous. Two coleiid genera have previously been known Upper Triassic strata, viz,, Pseudocoleia from the Norian-Rhaetian of Italy (Garassino \& Teruzzi, 1993; Garassino et al., 1996) and Tropifer from the Rhaetian of England (Duffin, 1978). The discovery of Coleia sp. in Carnian strata of Japan represents the oldest record, not only for the genus but also for the family.

The Eryonoidea typically contain four families, Coleiidae, Eryonidae (Upper Triassic-Lower Cretaceous), Polychelidae Wood-Mason (Middle JurassicRecent), and Tetrachelidae Beurlen (Upper Triassic). All genera, excluding the polychelids, have been known from the western Tethyan realm. Fossil members of the Polychelidae have been recorded from the Middle-Upper Jurassic of Europe (Glaessner, 1969), the Upper Jurassic of Antarctica (AguirreUrreta et al., 1990), and the Lower Oligocene of western North America (Schweitzer \& Feldmann, 2001). Extant polychelids are cosmopolitan in distribution (Galil, 2000). Amongst eryonoid genera, Rosenfeldia Garassino et al., Pseudocoleia, Tetrachela Reuss, and Tropifer are known from Upper Triassic deposits. The recognition of Coleia from 

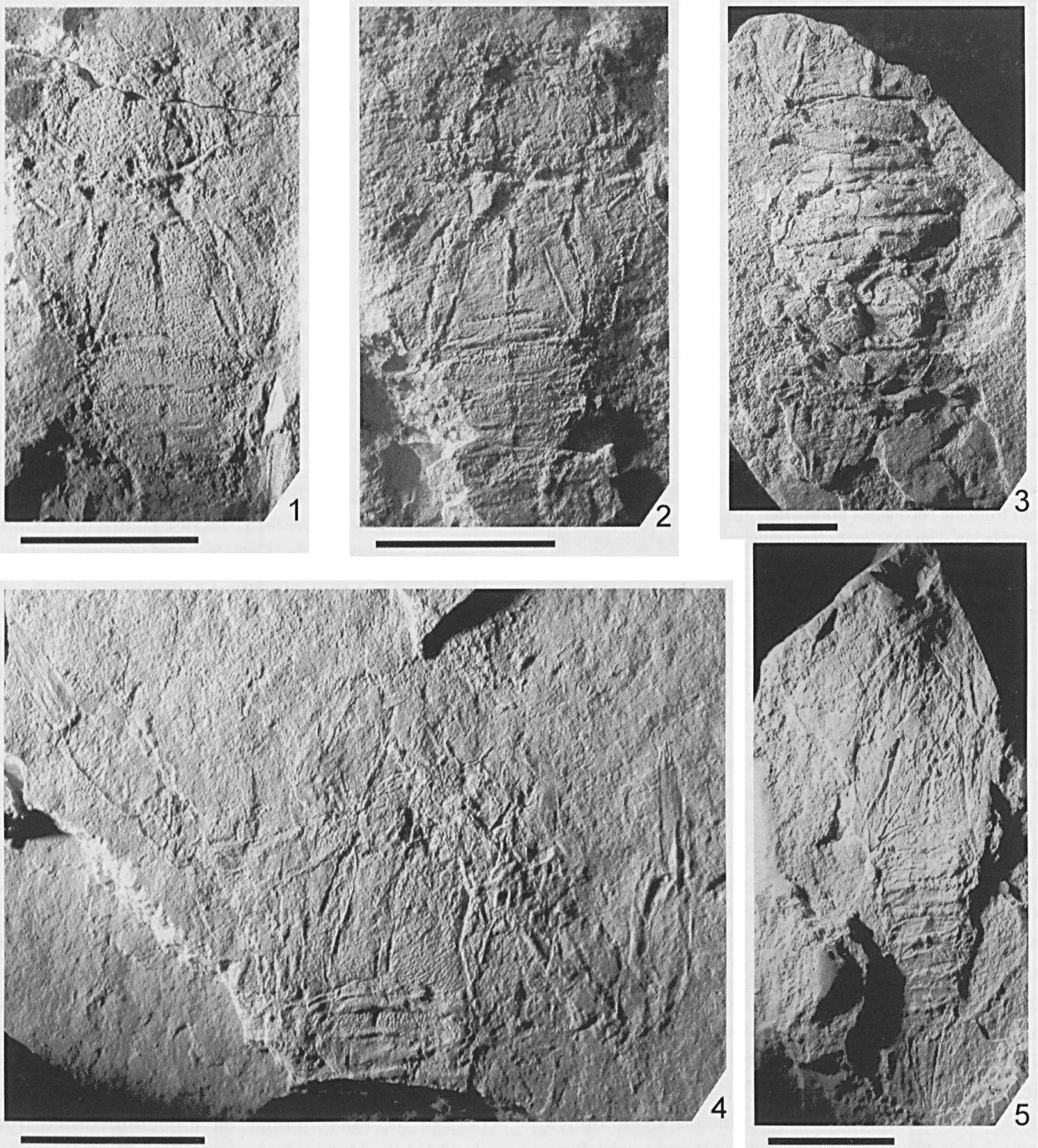

Fig. 1. Coleia sp. 1 - MMHF3-00039 (Mine City Museum of History and Folklore), external mould; 2 - MMHF3-00042, internal mould; 3 - MMHF3-00043, internal mould; 4 - MMHF3-00041, external mould; 5 - MMHF3-00040, external mould. Scale bars equal $10 \mathrm{~mm}$.

Japan greatly extends the known geographic range for the Triassic Eryonoidea to the western end of the Panthalassic Ocean.

\section{Acknowledgements}

We thank J.S.H. Collins (London), A. Garassino (Milano) and G. Schweigert (Stuttgart) for supplying items of literature. 


\section{References}

Aguirre-Urreta MB, Buatois LA, Chernoglasov GCHB, Medina FA. 1990. First Polychelidae (Crustacea, Palinura) from the Jurassic of Antarctica. Antarctic Sci. 2: 157-162.

Duffin CJ. 1978. Tropifer laevis Gould (Coleiidae: Crustacea) and a new crustacean from the Rhaetian Bone Bed of Aust Cliff, Avon. Zool. Jour. Linn. Soc. 64: 177-185.

Garassino, A, Teruzzi G. 1993. A new decapod crustacean assemblage from the Upper Triassic of Lombardy $(\mathrm{N}$. Italy). Paleont. Lombarda, n.s. 1: 1-27.

Garassino A, Teruzzi G, Dalla Vecehia FM. 1996. The macruran decapod crustaceans of the Dolomia di Forni (Norian, Upper Triassic) of Carnia (Udine, NE Italy). Atti Soc. it. Sci. nat. Museo civ. Stor, nat. Milano 136: 15-60.

Galil BS. 2000. Crustacea Decapoda: Review of the genera and species of the family Polychelidae Wood-Mason, 1874. In: Crosnier A. (ed.). Rèsultats des Campagnes MUSORSTOM, vol. 21. Mém. Mus. natn Hist. nat. Paris 184: 285-387.

Glaessner MF. 1969. Decapoda. In: Moore RC. (ed.). Treatise on Invertebrate Paleontology, Part R, Arthropoda 4:
R400-R566. Boulder: Geological Society of America/ Lawrence: University of Kansas Press.

Ishibashi T, Hashimoto K, Nohara M, Yoshida K. 1990. Triassic ammonites newly discovered in the western district of Yamaguchi Prefecture, Japan. Jour. Geol. Soc. Japan 96: 771-774.

Karasawa H. 2001. [Mesozoic decapod crustacean fauna of Japan]. Kaiyo Monthly, suppl. 26: 197-200 (in Japanese).

Karasawa H. 2002. Fossil uncinidean and anomalan Decapoda (Crustacea) in the Kitakyushu Museum and Institute of Natural History. Bull. Kitakyushu Mus.Nat. Hist. 21: 1316.

Schweigert G. 2000. News about Jurassic eryonid decapods (Coleiidae, Eryonidae) from southern Germany. Studi $e$ Ricerche, Assoc. Amici Museo civ. 'G. Zannato': 63-65.

Schweitzer CE, Feldmann RM. 2001. New Cretaceous and Tertiary decapod crustaceans from western North America. Bull. Mizunami Fossil Mus. 28: 173-210.

Tokuyama A. 1962. Triassic and some other organic sediments of the Akiyoshi cycle in Japan, with special reference to their evolution. Jour, Fac. Sci. Univ. Tokyo (2)13: 379-469.

Received: 15 March 2003 